\section{STATUS ANAK HASIL PERKAWINAN BEDA KEWARGANEGARAAN DI INDONESIA ${ }^{1}$}

Oleh : Veronica Katili ${ }^{2}$

\section{ABSTRAK}

Anak adalah subjek hukum yang belum cakap melakukan perbuatan hukum sendiri sehingga harus dibantu oleh orang tua atau walinya yang memiliki kecakapan. Sebelum di terbitkannya Undang-Undang No.12 Tahun 2006, Indonesia masih memakai Undang-Undang No.62 Tahun 1958 yang menganut Asas Kewarganegaraan Tunggal. Dimana kewarganegaraan anak mengikuti ayahnya. Sedangkan setelah UndangUndang No.12 Tahun 2006 di undangkan, maka Indonesia menganut sistem kewarganegaraan Ganda. Dimana anakanak yang lahir dari perkawinan campuran diberi dwi-kewarganegaraan oleh negara sampai anak tersebut berumur 18 tahun atau sudah kawin, setelah itu anak diberi kebebasan untuk memilih sendiri kewarganegaraan mana yang akan dia pilih. Pemberian kewarganegaraan ganda kepada anak oleh Undang-Undang Kewarganegaraan yang baru merupakan hal yang positif terutama dalam hubungan anak dengan ibu. Dimana anak bisa memilih sendiri kewarganegaraan pada saat dia dewasa nanti dan juga anak tidak serta merta mengikuti kewarganegaraan ayah. Jadi jika pada suatu saat terjadi perceraian diantara kedua orang tuanya, ibu tidak akan mendapatkan kesulitan untuk menemui anaknya seperti yang seringkali terjadi pada saat Undang-Undang No.12 Tahun 2006 ini belum di undangkan. Kemudian, untuk pendaftaran sendiri sudah ada langkahlangkah yang harus di ikuti guna mendapatkan kewarganegaraan Indonesia untuk anak dengan kewarganegaraan ganda tentunya harus melengkapi syaratsyarat yang sudah ditentukan.

\footnotetext{
${ }^{1}$ Artikel skripsi.

${ }^{2}$ NIM: 090711169.
}

Kata kunci: anak, perkawinan beda kewarganegaraan

\section{PENDAHULUAN}

\section{A. LATAR BELAKANG PENULISAN}

Perkawinan merupakan suatu peristiwa yang sangat penting bagi kehidupan masyarakat, karena perkawinan tidak hanya menyangkut hubungan antara pribadi calon suami istri tetapi juga menyangkut hubungan antara keluarga dan masyarakat

Perkawinan merupakan salah satu sarana untuk memenuhi kebutuhan manusia untuk memperoleh keturunan. Keturunan merupakan penerus bagi setiap keluarga. Dengan adanya perkawinan ini maka akan mengikat hubungan antara pribadi suami istri untuk membentuk suatu keluarga yang kekal dan bahagia.

Menurut K Wantjik Saleh (Hukum Perkawinan Indonesia) Perkawinan adalah suatu perjanjian yang diadakan oleh dua orang, dalam hal ini perjanjian antara seorang pria dengan seorang wanita dengan tujuan material, yakni membentuk keluarga (rumah tangga) yang bahagia dan kekal itu haruslah berdasarkan Ketuhanan Yang Maha Esa, sebagai asas pertama dalam Pancasila. ${ }^{3}$

Dalam Undang-Undang perkawinan pasal 1 menyebutkan bahwa "perkawinan ialah ikatan lahir batin antara seorang pria dengan seorang wanita sebagai suami istri dengan tujuan membentuk keluarga (Rumah tangga) yang bahagia dan kekal berdasarkan ketuhanan Yang Maha Esa". ${ }^{4}$

Dizaman globalisasi ini, kebutuhan hidup masyarakat sangat meningkat. Kebutuhan yang meningkat ini membawa suatu Negara terbuka atau melakukan hubungan internasional dengan Negara lain. Adanya

\footnotetext{
${ }^{3}$ Soedharyo Soimin, SH, Hukum Orang dan Keluarga Hal.6

${ }^{4}$ Undang-Undang No.1 Tahun 1974 Tentang Perkawinan
} 
hubungan internasional ini telah membantu masyarakat memenuhi kebutuhannya. Salah satunya adalah perkawinan, yang lebih kita kenal dengan perkawinan campuran.

Perkawinan campuran pasti sudah bukan hal yang asing di telinga kita. Banyak masyarakat di negara-negara maju yang telah mempraktekkan hal ini jauh sebelum negara kita mengenal juga apa yang disebut perkawinan campuran. Banyak masyarakat Indonesia yang telah melakukan perkawinan campuran, baik itu dengan orang-orang Eropa, Australia, Amerika, Afrika dan Asia. Oleh karna itu sudah seharusnya perlindungan hukum dalam perkawinan campuran di akomodir dengan baik dalam perundang-undangan di Indonesia.

Perkawinan beda kewarganegaraan telah merambah seluruh pelosok Tanah Air dan kelas masyarakat. Menurut survey yang dilakukan oleh Mixed Couple Club, jalur perkenalan yang membawa pasangan berbeda kewarganegaraan menikah antara lain adalah perkenalan melalui internet, kemudian bekas teman kerja/bisnis, berkenalan saat berlibur, bekas teman sekolah/kuliah, dan sahabat pena. 5 Perkawinan beda kewarganegaraan juga terjadi pada tenaga kerja Indonesia dengan tenaga kerja dari negara lain.

Perkawinan beda kewarganegaraan bukanlah suatu hal yang mudah, ada banyak hal yang nantinya dapat menjadi suatu masalah dikemudian hari.

Salah satu hal yang biasanya menjadi kendala bagi orang yang melaksanakan perkawinan beda kewarganegaraan baik di dalam maupun diluar negeri, adalah mengenai perlindungan hukum apabila dalam perkawinan di Indonesia misalnya terjadi perceraian yang berimbas dalam hal pembagian harta, hak asuh anak dan sebagainya. Hal ini tentu saja menyulitkan lembaga perkawinan di Indonesia dalam

\footnotetext{
${ }^{5}$ http://norickyujustice.blogspot.com diakses 02 November 2012 pukul 4.53 pm

proses penyelesaiannya karena mereka melangsungkan perkawinan diluar negeri. Keadaaan ini memberikan anggapan bahwa Undang-Undang perkawinan dinilai tidak memberikan perlindungan terhadap warganya yang melangsungkan pernikahan beda negara. Sehingga tidak adanya kepastian hukum, padahal mereka adalah warga Negara yang mempunyai hak untuk di lindungi.

\section{B. PERUMUSAN MASALAH}

1. Bagaimana pengaturan status hukum anak yang lahir dari perkawinan beda kewarganegaraan sebelum dan sesudah lahirnya undang-undang Kewarganegaraan yang baru?

2. Bagaimana cara pendaftaran kewarganegaraan Indonesia bagi anak dengan kewarganegaraan ganda?

\section{METODE PENELITIAN}

Oleh karena ruang lingkup penulisan ini adalah pada disiplin ilmu hukum, maka penelitian ini merupakan bagian dari penelitian hukum kepustakaan yakni dengan cara "Meneliti bahan pustaka" selain itu penulis juga melakukan penelitian terhadap asas-asas hukum atau yang dinamakan "Penelitian Hukum Normatif". ${ }^{6}$

Dalam penelitian skripsi penulis menggunakan metode pengumpulan data dan metode pengelolahan data sebagai berikut

\section{Metode Pengumpulan Data}

Untuk mengumpulkan data, maka penulis telah mempergunakan metode penelitian kepustakaan (Library Research) yakni suatu metode yang digunakan dengan cara mempelajari buku literatur, perundang-undangan dan bahan-bahan tertulis lainnya yang berhubungan dengan materi pembahasan untuk mendukung pembahasan ini.

\section{Metode Pengelolahan Data}

\footnotetext{
${ }^{6}$ Bambang Sunggono, SH, M.S "Metodologi Penelitian Hukum" Jakarta : Rajawali Pers 2011
} 
Data yang terkumpul kemudian diolah dengan suatu teknik pengelolahan data secara deduksi dan Induksi sebagai berikut :

a. Secara Deduksi, yaitu pembahasan yang bertitik tolak dari hal-hal yang bersifat umum kemudian di bahas menjadi suatu kesimpulan yang bersifat khusus.

b. Secara induksi yaitu pembahasan yang bertitik tolak dari hal-hal yang bersifat khusus, kemudian dibahas menjadi suatu kesimpulan yang bersifat umum (merupakan kebalikan dari Metode Deduksi).

Kedua metode dan teknik pengelolahan data tersebut di atas dilakukan secara berganti-gantian bilamana perlu untuk mendukung pembahasan Skripsi ini.

\section{PEMBAHASAN}

\section{A. PENGATURAN STATUS HUKUM ANAK SEBELUM DAN SESUDAH LAHIRNYA UNDANG-UNDANG KEWARGANEGARAAN YANG BARU}

\section{Sebelum Lahirnya Undang-Undang No.12 Tahun 2006}

Di Indonesia ada suatu peraturan yang mengatur pasangan perkawinan campuran jika melahirkan seorang anak, maka kewarganegaraan anak tersebut diatur oleh Undang-Undang yang berlaku.

Sebelum lahirnya Undang-Undang No.12 Tahun 2006 tentang Kewarganegaraan, Indonesia memang lebih dahulu mengenal Undang-Undang No.62 Tahun 1958 tentang kewarganegaraan.

Di dalam Undang-Undang No.62 Tahun 1958 dikatakan bahwa anak yang lahir dari perkawinan campur hanya bisa memiliki satu kewarganegaraan dan ditentukan hanya mengikuti kewarganegaraan ayahnya. Undang -Undang No.62 Tahun 1958 menganut asas kewarganegaraan tunggal, dimana kewarganegaraan anak mengikuti ayah, sesuai pasal 13 ayat (1). ${ }^{7}$

Pasal III Peraturan Penutup UndangUndang No.62 Tahun 1958 menentukan bahwa anak yang belum berusia 18 (delapan belas) tahun atau belum kawin dianggap bertempat tinggal sama dengan ayah dan ibunya ${ }^{8}$.

Ketentuan dalam Undang-Undang No.62 Tahun 1958 dianggap tidak memberikan perlindungan hukum yang cukup bagi anak yang lahir dari perkawinan campuran dan diskriminasi terhadapWarga Negara Indonesia baik perempuan maupun lakilaki.

Dalam ketentuan Undang-Undang Kewarganegaraan ini, anak yang lahir dari perkawinan campuran bisa menjadi Warga Negara Indonesia dan bisa menjadi Warga Negara Asing karena ${ }^{9}$ :

a. Anak yang lahir dari perkawinan campuran antara seorang pria Warga Negara Indonesia dengan perempuan Warga Negara Asing, maka kewarganegaraan anak mengikuti ayahnya (WNI).

Apabila anak tersebut lahir dari perkawinan antara seorang wanita WNA dengan pria WNI (pasal 1 huruf $b$ UU No.62 Tahun 1958), maka kewarganegaraan anak mengikuti ayahnya. Kalaupun Ibu dapat memberikan kewarganegaraannya, si anak terpaksa harus kehilangan kewarganegaraan Indonesianya. Bila suami meninggal dunia dan anak-anak masih dibawah umur tidak jelas apakah istri dapat menjadi wali bagi anak-anak nya yang menjadi WNI di Indonesia. Bila suami (yang berstatus pegawai negeri) meningggal tidak jelas apakah istri

\footnotetext{
${ }^{7}$ Undang-Undang No.62 Tahun 1958 tentang Kewarganegaraan

${ }^{8}$ Koerniatmanto Soetoprawiro, Hukum

Kewarganegaraan dan Keimigrasian Hal.41

${ }^{9}$ http://wartawarga.gunadarma.ac.id diakses 21 januari 2013 pukul 6.55 pm
} 
(WNA) dapat memperoleh pensiun suami.

b. Anak yang lahir dari perkawinan campuran antara seorang perempuan Warga Negara Indonesia dengan pria Warga Negara Asing, maka anak tersebut dianggap sebagai WNA.

Apabila anak tersebut lahir dari perkawinan antara seorang wanita warganegara Indonesia dengan warganegara asing. Anak tersebut sejak lahirnya dianggap sebagai warga negara asing sehingga harus dibuatkan Paspor di Kedutaan Besar Ayahnya, dan dibuatkan kartu Izin Tinggal Sementara (KITAS) yang harus terus diperpanjang dan biaya pengurusannya tidak murah. Dalam hal terjadi perceraian, akan sulit bagi ibu untuk mengasuh anaknya, walaupun pada pasal 3 UU No.62 Tahun 1958 dimungkinkan bagi seorang ibu WNI yang bercerai untuk memohon kewarganegaraan Indonesia bagi anaknya yang masih di bawah umur dan berada dibawah pengasuhannya, namun dalam praktek hal ini sulit dilakukan.

\section{Sesudah Lahirnya Undang-Undang No.12 Tahun 2006}

Pengesahan

Undang-undang

Kewarganegaraa No. 12 Tahun 2006 merupakan momentum bersejarah bagi seluruh masyarakat Indonesia. Kelahiran undang-undang ini memiliki nilai historis karena produk hukum yang digantikan, yakni Undang-undang No. 62 Tahun 1958 merupakan peninggalan rezim orde lama yang dilestarikan orde baru.

Menurut

Undang-undang

Kewarganegaraan Tahun 2006 dalam Pasal 2 disebutkan bahwa yang menjadi Warga Negara Indonesia adalah orang-orang bangsa Indonesia asli dan orang-orang bangsa lain yang disahkan degan UndangUndang sebagai Warga Negara ${ }^{10}$.

\footnotetext{
${ }^{10}$ Undang-Undang No.12 Tahun 2006 tentang Kewarganegaraan Hal.3

Dalam Undang-Undang yang baru ini juga disebutkan, WNI yang menikah dengan pria WNA tidak lagi dianggap otomatis mengikuti kewarganegaraan suaminya, melainkan diberi tenggang waktu tiga tahun untuk menentukan pilihan, apakah akan tetap menjadi WNI atau melepaskannya. Selain itu, apabila istri memutuskan tetap menjadi WNI atau selama masa tenggang waktu tiga tahun itu, ia bisa menjadi sponsor izin tinggal suaminya di Indonesia ${ }^{11}$.

Sejak Undang-Undang No.12 Tahun 2006 dikeluarkan maka secara otomatis Indonesia menganut Kewarganegaraan ganda.

Berkewarganegaraan ganda berarti seorang anak yang lahir dari perkawinan campuran dapat memiliki kewarganegaraan ayah dan ibunya atau sering dikatakan dengan Kewarganegaraan Ganda atau juga Dwi Kewarganegaraan sampai batas umur 18 tahun atau kawin. Dan paling lambat 3 tahun setelah berusia 18 tahun atau telah kawin harus menyatakan memilih satu kewarganegaraannya ${ }^{12}$.

Berdasarkan

Undang-Undang kewarganegaraan yang baru ini anak yang lahir dari perkawinan seorang wanita WNI dengan pria WNA, maupun anak yang lahir dari perkawinan seorang wanita WNA dengan pria WNI, sama-sama diakui sebagai warga negara Indonesia. ${ }^{13}$

Pemberian kewarganegaraan ganda merupakan hal yang positif bagi anak-anak yang terlahir dari perkawinan campur, memang sasaran dari Undang-Undang ini adalah untuk melindungi anak-anak hasil perkawinan WNI dengan pria WNA, juga bagi anak-anak yang lahir dan tinggal diluar negeri. Namun disisi lain kebijakan ini akan menimbulkan masalah bagi anak

\footnotetext{
${ }^{11}$ J.G. Starke, Pengantar Hukum Internasional Hal.125

${ }^{12}$ Undang-Undang No.12 Tahun 2006 pasal 60 ayat (1)

${ }^{13}$ Lihat Pasal 4 huruf c dan d Undang-Undang No.12 Tahun 2006 tentang Kewarganegaraan
} 
dikemudian hari, karena memiliki dwi kewarganegaraan berarti tunduk pada dua yuridiksi hukum yang berbeda.

\section{B. CARA} KEWARGANEGARAAN BAGI ANAK KEWARGANEGARAAN GANDA

Cara pendaftaran kewarganegaraan bagi anak adalah sebagai berikut ${ }^{14}$ :

1. Pendaftaran untuk memperoleh Kewarganegaraan Republik Indonesia bagi anak dilakukan oleh salah seorang dari orang tua atau walinya dengan mengajukan permohonan secara tertulis dalam Bahasa Indonesia diatas kertas bermaterai cukup.

2. Permohonan pendaftaran bagi anak yang bertempat tinggal di Wilayah Negara Republik Indonesia diajukan kepada Menteri melalui Pejabat yang wilayah kerjanya meliputi tempat tinggal anak.

3. Permohonan pendaftaran bagi anak yang bertempat tinggal diluar Wilayah Negara Republik Indonesia diajukan kepada Menteri melalui Kepala Perwakilan Republik Indonesia yang wilayah kerjanya meliputi tempat tinggal anak.

4. Dalam hal di Negara tempat tinggal anak belum terdapat Perwakilan Republik Indonesia, maka permohonan pendaftaran dilakukan melalui Kepala Perwakilan Republik Indonesia terdekat.

\section{PENUTUP}

\section{A. KESIMPULAN}

1. Anak adalah subjek hukum yang belum cakap melakukan perbuatan hukum sendiri sehingga harus dibantu oleh orang tua atau walinya yang memiliki

\footnotetext{
${ }^{14}$ http://www.indosiar.com diakses 21 januari 2013 pukul $7.03 \mathrm{pm}$
}

kecakapan. Sebelum di terbitkannya Undang-Undang No.12 Tahun 2006, Indonesia masih memakai UndangUndang No.62 Tahun 1958 yang menganut Asas Kewarganegaraan Tunggal. Dimana kewarganegaraan anak mengikuti ayahnya. Sedangkan setelah Undang-Undang No.12 Tahun 2006 di undangkan, maka Indonesia menganut sistem kewarganegaraan Ganda. Dimana anak-anak yang lahir dari perkawinan campuran diberi dwi-kewarganegaraan oleh negara sampai anak tersebut berumur 18 tahun atau sudah kawin, setelah itu anak diberi kebebasan untuk memilih sendiri kewarganegaraan mana yang akan dia pilih. Pemberian kewarganegaraan ganda kepada anak oleh Undang-Undang Kewarganegaraan yang baru merupakan hal yang positif terutama dalam hubungan anak dengan ibu. Dimana anak bisa memilih sendiri kewarganegaraan pada saat dia dewasa nanti dan juga anak tidak serta merta mengikuti kewarganegaraan ayah. Jadi jika pada suatu saat terjadi perceraian diantara kedua orang tuanya, ibu tidak akan mendapatkan kesulitan untuk menemui anaknya seperti yang seringkali terjadi pada saat UndangUndang No.12 Tahun 2006 ini belum di undangkan.

2. Cara pendaftaran kewarganegaraan bagi anak adalah sebagai berikut: a. Pendaftaran untuk memperoleh Kewarganegaraan Republik Indonesia bagi anak dilakukan oleh salah seorang dari orang tua atau walinya dengan mengajukan permohonan secara tertulis dalam Bahasa Indonesia diatas kertas bermaterai cukup; b. Permohonan pendaftaran bagi anak yang bertempat tinggal di Wilayah Negara Republik Indonesia diajukan kepada Menteri melalui Pejabat yang wilayah kerjanya meliputi tempat tinggal anak; c. Permohonan pendaftaran bagi anak 
yang bertempat tinggal diluar Wilayah Negara Republik Indonesia diajukan kepada Menteri melalui Kepala Perwakilan Republik Indonesia yang wilayah kerjanya meliputi tempat tinggal anak; d. Dalam hal di Negara tempat tinggal anak belum terdapat Perwakilan Republik Indonesia, maka permohonan pendaftaran dilakukan melalui Kepala Perwakilan Republik Indonesia terdekat.

\section{B. SARAN}

Kiranya Negara ini semakin memperbaiki kinerja para petugas dalam mengurusi pendaftaran kewarganegaraan bagi anak dengan kewarganegaraan ganda. Saya juga menyarankan agar Undang-Undang No.12 Tahun 2006 yang dimana anak diberikan kebebasan untuk memilih kewarganegaraan pada saat dia sudah menikah dipertimbangkan lagi. Hal ini penting karena menurut saya, hal ini akan menimbulkan masalah baru karena Hukum yang ada di Indonesia tidak sama dengan Hukum dinegara lain, terlebih lagi Hukum dalam masalah perkawinan. Saya juga menyarankan agar Undang-Undang kewarganegaraan di Indonesia dapat dilakukan dengan baik sehingga dapat berjalan dengan lancar.

\section{DAFTAR PUSTAKA}

Bahan Ajar Hukum Perdata Internasional Fakultas Hukum Universitas Sam Ratulangi Manado.

Bambang Sunggono, S.H. MS, Metodologi Penelitian Hukum PT. Raja Grafindo Persada, Jakarta.

J.G Starke, _ _ Pengantar Hukum Internasional, Sinar Grafika.

Koerniatmanto Soetoprato 1996, Hukum Kewarganegaraan dan Keimigrasian Indonesia, PT. Gramedia Pustaka Utama, Jakarta.

Prof. H. Hilman Hadikusuma, SH 2007, Hukum Perkawinan Indonesia, CV. Mandar Maju, Bandung
Purnadi Purbacaraka, 1997, Sendi-Sendi Hukum Perdata Internasional, Raja Grafindo Persada, Jakarta.

Soedharyo Soimin, S.H, Hukum Orang dan Keluarga, Sinar Grafika, Jakarta.

\section{Undang-Undang}

Undang-Undang No.12 Tahun 2006 Tentang Kewarganegaraan.

Undang-Undang No.1 Tahun 1974 Tentang Perkawinan.

\section{Sumber-Sumber Lainnya}

Http://Noricyujustice.blogspot.com, Status

Hukum Anak Dari Hasil Perkawinan Campuran Berdasarkan Hukum Nasional Indonesia, 02 November 2012 Pukul 4:53 pm

Http://Ras-eko.blogspot.com, Pengertian Kewarganegaraan Menurut Para Ahli 21Januari 2013 Pukul 6:26 pm

Http://www.Indosiar.com, Undang-Undang Kewarganegaraan Baru, Metode Lama, 21 Januari 2013 Pukul 7:03 pm

Http://Hukumonline, Prosedur Pengurusan Kewarganegaraan Anak Masih Dikeluhkan 21 Januari 2013 Pukul 6:59 